\title{
A PROPOSAL FOR DESERT HOUSE DESIGN IN EGYPT USING PASSIVE GROUND COOLING TECHNIQUES
}

\author{
Prof. Dr. Mohamed Medhat Dorra ${ }^{1}$, Assoc. Prof. Dr. Hend El-Sayed Farouh² and Eng. Lubna A. Amer ${ }^{3}$ \\ Department of Electrical Power and Machines Engineering, Tanta University, Tanta, Egypt \\ ${ }^{1}$ Professor of Architecture, Faculty of Engineering, Cairo University, Giza, Egypt. \\ ${ }^{2}$ Associate Prof. of Sustainable Architecture \& Urban Development, Housing \& Building National Research Center, Giza, \\ Egypt \\ ${ }^{3} \mathrm{PhD}$ candidate, Faculty of Engineering, Cairo University, Giza, Egypt \\ hfarouh@imc-egypt.org, lamer@mdd-architects.com
}

\begin{abstract}
An area less than 5.5\% of Egyptian territory is where most of Egypt's population lives. A narrow strip of land forms the Nile Valley and Delta sector.

The National Project for Desert Hinterlands is one of the urban projects targeting rehabilitation of the poor in alternative villages in the near desert to stop urban sprawl over agricultural land and decrease congestion in the old habitats. Low cost energy efficient houses are the aim of the architect in similar projects taking in consideration the high electricity consumption of Egypt's residential sector.
\end{abstract}

Based on a literature review, this paper presents a proposal for designing desert dwellings that accommodate the hot dry climate by incorporating passive elements and using stabilized earth blocks as a local building material. Furthermore, simulation is used to test alternative proposals. The results show that an underground constructed house with a sunken courtyard incorporating an Earth to Air Heat Exchanger System (EAHE) can reduce between 42$72 \%$ of energy consumption used to achieve thermal comfort compared to contemporary desert housing projects.

Keywords - Earth Sheltered Houses, Earth to air heat Exchangers, Earth cooling Tubes, low cost energy efficient desert house.

\section{INTRODUCTION}

The need has arisen to undertake extensive projects for redistributing the population. The Desert Hinterlands Villages is one of these projects to establish low cost desert housing. These projects should be low cost energy efficient to avoid the increasing energy demand due to cooling needs.
Farouh and Amer [1] explored the main passive and hybrid design techniques for low cost energy efficient housing in hot arid climate. They highly recommended using the technique of "cooling by thermal earth inertia". This was the starting point for this research in which an approach - to implement these techniques - was examined by computer modeling using Design Builder Program experimenting a proposed Earth sheltered Building with a sunken courtyard and using Underground Earth Tubes.

\section{Aim of the Study}

The authors constructed this work on implementing passive ground cooling techniques as a proposal for enhancing thermal performance of desert houses in Egypt. The aim is to examine the ability of this proposal in saving energy and achieving thermal comfort in low cost desert housing in Egypt.

\section{Egypt's Background}

A quick look at Egypt's conditions related to our study.

\section{Egyptian electricity consumption}

The Building Sector consumes most of the electricity (See Fig.1) due to the increased consumption of the air conditioning machines [2], [3]. 


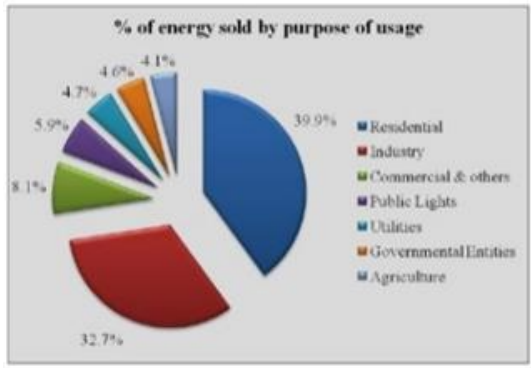

Fig .1. Egyptian electricity consumptionThe most consuming areas are the residential ones. The Egyptian Electricity Holding Company Annual Report 2009/2010. Egyptian Electricity Holding Company, Cairo, Egypt, 2010.

\section{A. Groundwater levels}

The ground water is found far below the ground surface in most Egypt's desert area [4] (See Fig. 2). Therefore, excavations are implemented easily without the need for water proof materials.

\section{B. Type of soil:}

Most Egypt's desert land is a sandy soil and easy to construct on. Thermal characteristics of soil affect the underground temperatures, which is a major factor in energy saving by earth inertia as will be explained later.

\section{LITERATURE REVIEW : PASSIVE GROUND COOLING}

The concept of ground cooling is based on heat dissipation from a building to the ground which, during the cooling season, has a temperature lower than the outdoor air. This dissipation can be achieved either by direct contact of a significant areas of the building envelope with the ground (Earth shelters), or by injecting air that has been previously circulated underground into the building by means of earth-toair heat exchangers (EAHE).

\section{Heat Storage Capacity of the Earth Subsurface}

The rocks at the subsurface have high value of volumetric heat capacity but low value of thermal conductivity. Therefore, the heat is rather stored than diffuses through the soil in the upstream [5].

When averaged globally and annually, about $49 \%$ of the solar radiation striking the earth and its atmosphere is absorbed at the surface [6] (See Fig. 3).

\section{Earth Shelters}

Researchers, including Anselm [6], found that earth sheltered houses maintain heating energy consumption lesser by up to $75 \%$ compared to conventional above-ground house.

\section{A. Definition}

Earth shelters can be defined as structures built with the use of earth mass against building walls as external thermal mass [7].

\section{B. Potential energy savings:}

Based on several physical characteristics: [9]

- The reduction of heat loss due to conduction through the building envelope.

- Less heat conduction into the house due to reduced temperature differential.

- Building protection from the direct solar radiation.

- The reduction of air infiltration within the dwelling.

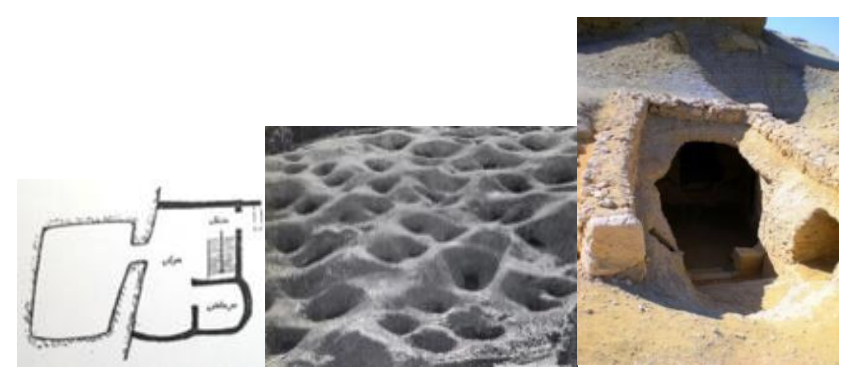

(a) One of the partially buried homes in Siwa 

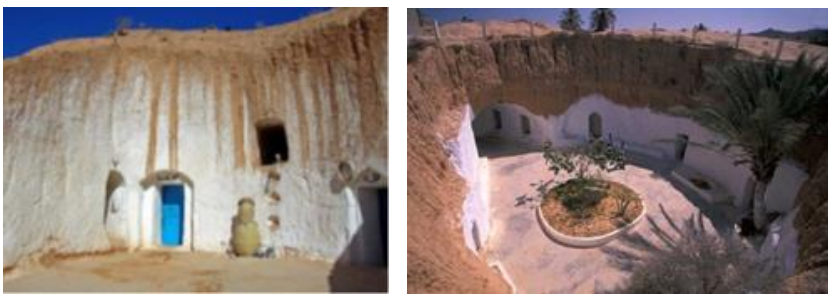

(b) Aerial view of a typical Matmata earth shelter dwelling.
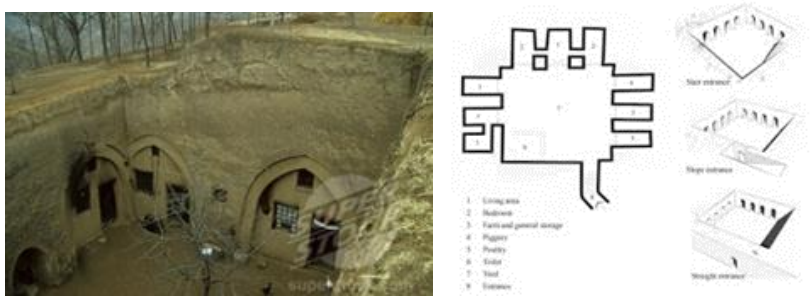

(c) A typical earth shelter home in North-western China

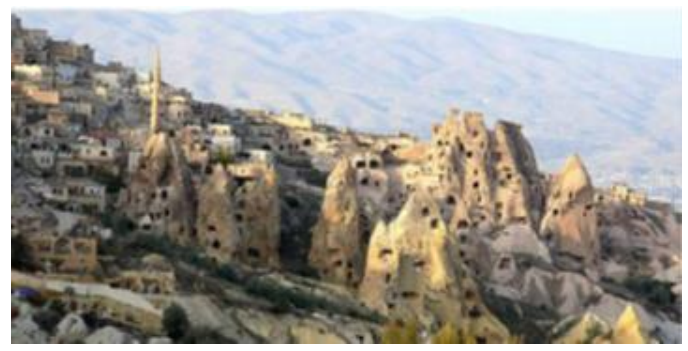

(d) The Goreme Valley of Cappadocia in central Turkey

Fig .4. Historical Earth sheltered homes [8-10]

\section{Historical background and examples}

Earth sheltered homes were primarily developed for shelter, warmth and security for the earliest human dwellers. Most of the recorded cases of these shelters are found extensively in areas like Asia and Northern Africa.

- In Egypt: [8] such as: Nazlet Elsemman in Giza (for historical conservation reasons), Paris village in Upper Egypt \& Siwa oasis in western desert (for climatic protection reasons).

- In Tunisia: [Dry Desert climate]: Residents of Matmata and in Bulla Regia, use of the sunken courtyard concept [9].

- In China: [Humid subtropical climate]: Yaodongs cave houses carved out of a hillside or excavated horizontally from a central "sunken courtyard" An estimated 40 million people live in Yaodongs [10].
- In Turkey: The Goreme Valley of Cappadocia [Dry Steppe climate]: $260 \mathrm{~km} 2$ with 200+ underground villages complete with hidden passages, secret rooms and ancient temples (See Fig. 4).

\section{Typology}

- Bermed earth shelter: Earth is piled up against exterior walls and heaped to incline downwards away from the house. The roof may, or may not be, fully earth covered. Other variations are the elevational and in-hill. As in Turkey (See Fig. 4).

- Envelope or True underground earth shelter: The house is built completely below ground on a flat site, with the major living spaces surrounding a central outdoor courtyard or atrium which provides light, solar heat, outside views, and access via a stairway from the ground level,as in Tunisia and China (See Fig. 4).

About $50 \%$ of the elevational structures exterior façade is in direct contact with the earth mass, while the ratio is $80 \%$ of Atrium design and hence becomes an underground building type which offers better indoor conditions for both summer and winter temperatures [8], [11].

\begin{tabular}{|l|l|l|l|}
\hline $\begin{array}{l}\text { On the } \\
\text { Hillside }\end{array}$ & Bermed & Underground & $\begin{array}{l}\text { Relation } \\
\text { Surface }\end{array}$ \\
\cline { 3 - 4 } & & Openings \\
\hline
\end{tabular}

\section{E. Worldwide earth sheltered houses:}

Will be explored to explain the typology of earth sheltered houses and enrich the knowledge of key projects of these types. 
Table 1. Some Worldwide Earth Sheltered Housing Units

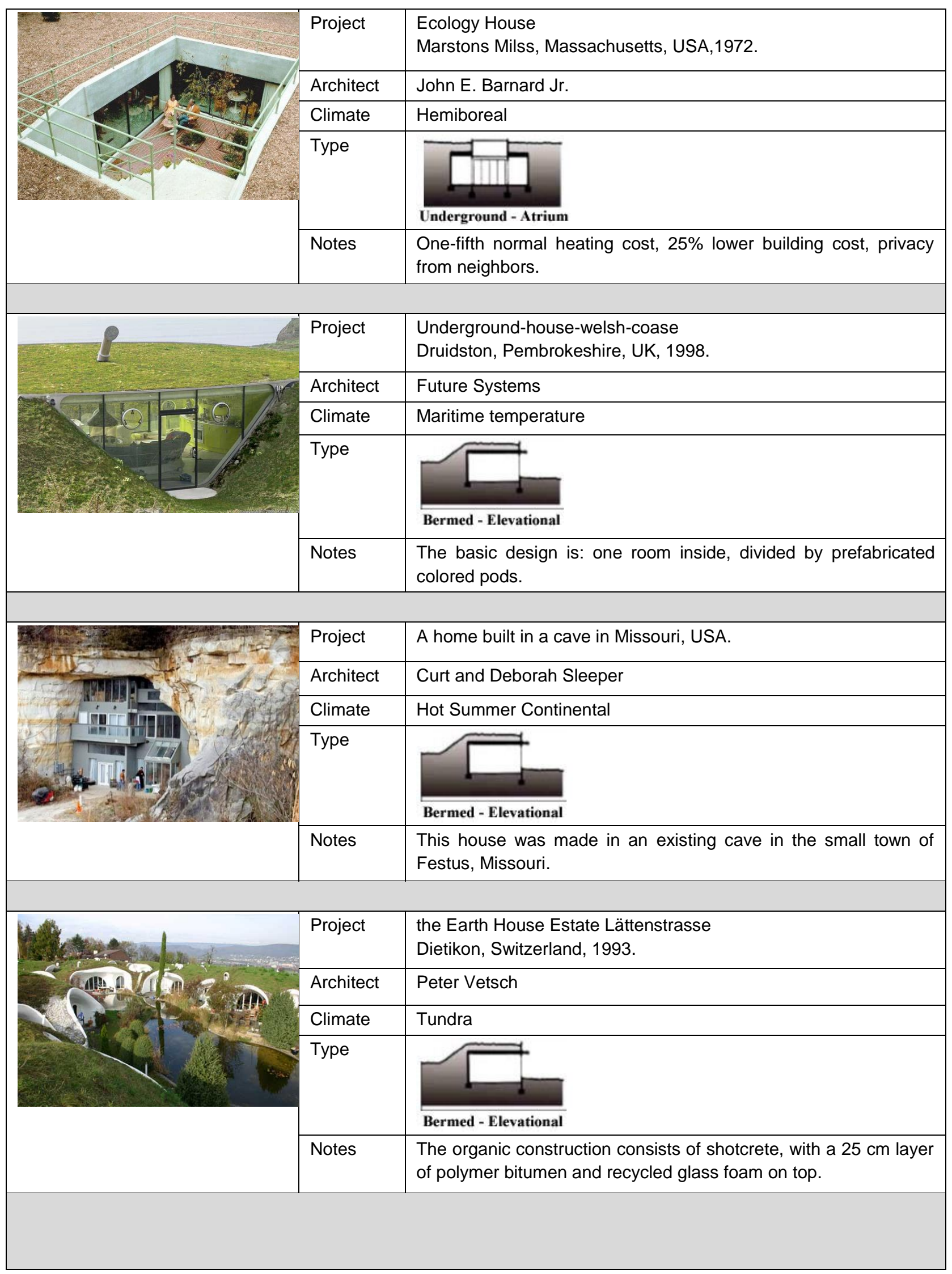



http://dx.doi.org/10.21622/RESD.2018.04.1.021

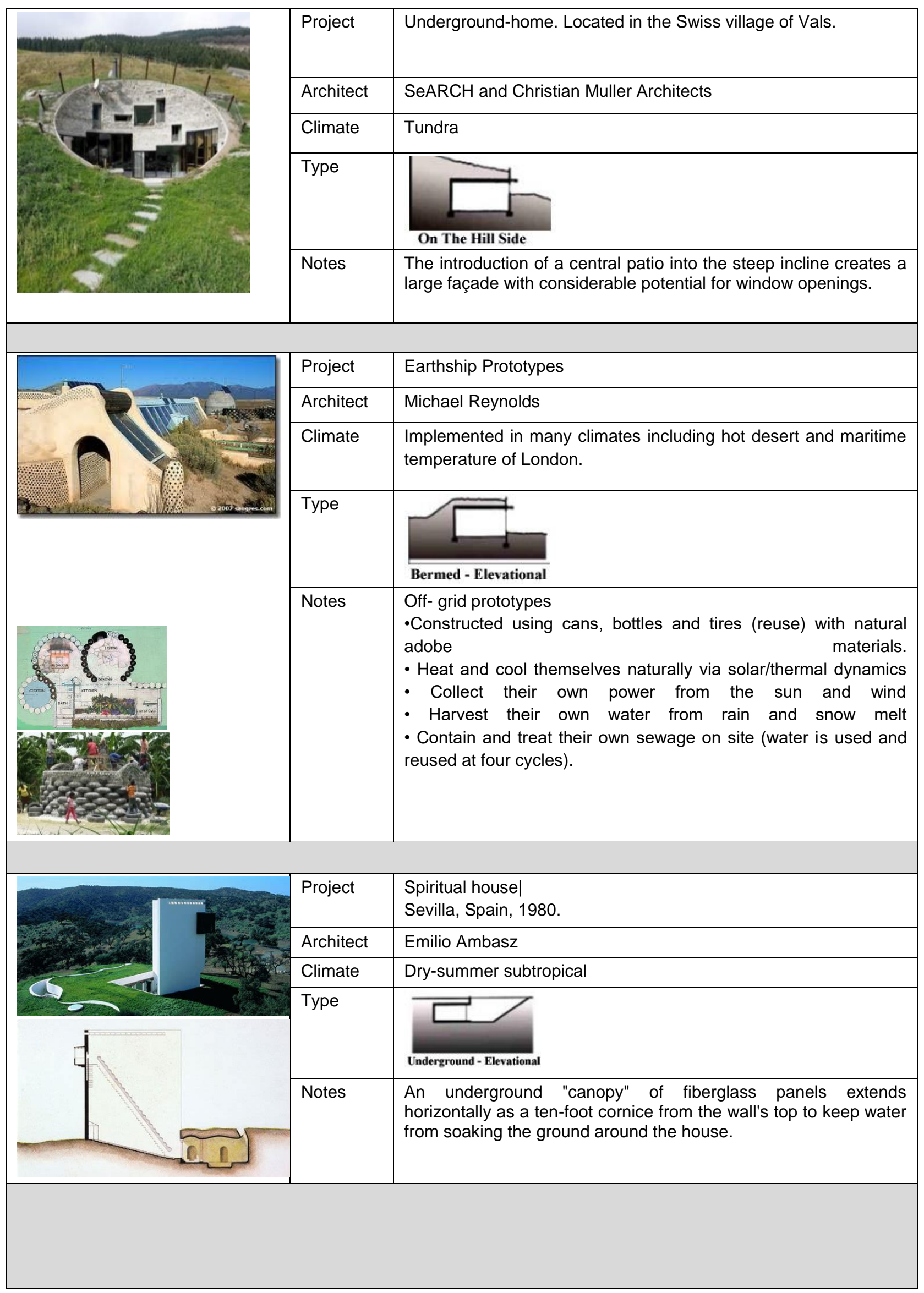



http://dx.doi.org/10.21622/RESD.2018.04.1.021

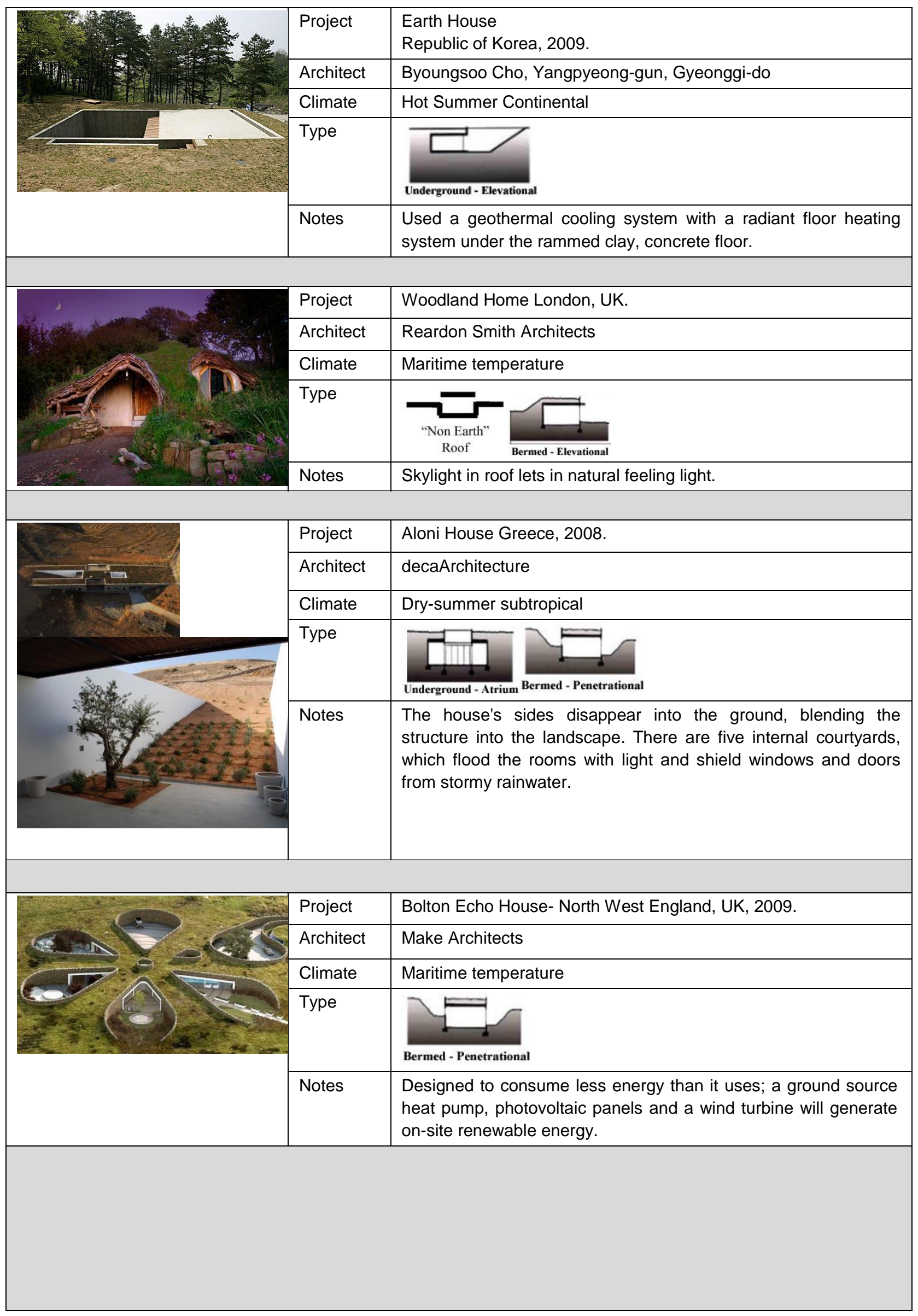




\begin{tabular}{|l|l|l|}
\hline & Project & CoolTek House in Malacca, Malaysia. \\
\hline
\end{tabular}

\section{F. Ventilation system and air infiltration:}

To avoid sick building syndrome and ensure a desirable and healthy environment, the underground building units are usually incorporated with various types of passive induced ventilation techniques [12].

\section{G. Advantages and disadvantages- Advantages:}

Underground homes provide a safer living environment [13] [14], energy Efficiency compared to aboveground homes [15] [16], reduced maintenance-operating costs, and construction efficiencies. In addition to minimal visual impact, dual land use, and lower noise [17].

Disadvantages: Social acceptance: Golany stated that there are some social and psychological problems to overcome in earth-sheltering [18]. But Al-mumin found that in Kuwait the occupants agreed to live underground and sunken courtyards are preferred [19]. Thus negative aspects could be avoided by a good efficient design and a sufficient exposure to sunlight through elevations or sunken courtyards.

\section{H. Construction cost:}

Al-Mumin concluded that underground courtyard homes are almost the same if not less expensive than aboveground ones [19]. The reduction is due to savings in the exterior cladding, wall materials, and thermal insulation, we must consider the running costs and thus the sunken courtyard concept may win [20]. However, additional studies are needed to investigate and to prove this point.

\begin{tabular}{|c|c|}
\hline Advantages & Disadvantages \\
\hline Minimal visual & Lack of outside \\
\hline Thermal efficiency & Public \\
\hline Increased open & Lack of thermal \\
\hline Lower noise & Higher excavation \\
\hline Reduced & Water drainage \\
\hline Safer living & Ventilation * \\
\hline Construction & Design constrains \\
\hline Reduced life cycle & \\
\hline \multicolumn{2}{|c|}{${ }^{*}$ ) means could be avoided by aspects of good } \\
design \\
\hline
\end{tabular}

\section{Construction considerations}

- Climate: In dry climates with high temperature extremes - as in Egypt's Desert - earth-sheltered houses can be more cost-effective [20].

- Site's topography and microclimate: Flat sites - as in Egypt's desert - is the most demanding for excavations [20].

- Type of soil: Sandy soils are the best for earthsheltered houses because they compact well for bearing the weight of the construction materials and allow water to drain quickly, which protects the underground constructions [20].

- The groundwater level: underground water exerts pressure against underground bearing 
walls so it is important to build above the water table [20].

\section{J. Construction materials}

Earth sheltered houses require heavy duty, more enduring construction materials that can resist the pressure and moisture of the surrounding ground [due to their good waterproofing and insulation properties]. Concrete, reinforced masonry, steel, and wood can be suitable.

In developing countries, local materials have been used widely for their advantages economically, ecologically, and good energy performance. Examples are cob, adobe, straw bale, brick, wood, cordwood, and stone [21]. Here's some recently proposed materials for low cost housing in Egypt:

Rice-straw based cement brick: The rice-straw has replaced part of the aggregates used in the normal cement brick to generate a stable blend after which mechanical and thermal experiments have been conducted [22]. It showed promising energy savings but this material is presented mainly as a solution for recycling rice wastes and has not been widely approached in Egypt.

"Rammed Earth" is constructed by using a pneumatic tamper to ram a mix of earth and cement, into wall forms to produce walls, foundations and floors. The soil should have some silt and clay to act as binders and allow soil compaction which are not available in desert soils as the case in this research. Also, rammed earth cannot be used for constructing ceilings. Actually there is a lack of knowledge and access to tools for using this material in Egypt [23].

\section{The compressed stabilized earth block}

Using a steel press to compress the moisturized soil raw or stabilized-producing CSEB blocks. Sandy soil is more suitable than clayey one.
Cement is preferred as a stabilizer for sandy soils to accelerate the strength. The ratio of cement should be around $5 \%$.

A finished $\mathrm{m} 3$ of CSEB masonry is always cheaper than fired bricks: $19.4 \%$ less than country fired bricks and $47.2 \%$ less than wire cut bricks [24].

In addition to its advantages, stabilized earth blocks also introduce a solution for reusing the excavated soil from basement in underground courtyard homes so the research recommends stabilized earth blocks as a building material for earth sheltered houses in Egypt's desert.

Table 3. .Advantages of "CSEB" [24]

\begin{tabular}{|c|c|}
\hline A local material & \multirow{2}{*}{$\begin{array}{c}\text { Socially accepted } \\
\text { Flexible production } \\
\text { scale }\end{array}$} \\
\hline $\begin{array}{c}\text { A bio-degradable } \\
\text { material }\end{array}$ & \\
\hline $\begin{array}{l}\text { An adapted material: } \\
\text { Produced locally }\end{array}$ & Cost efficiency \\
\hline $\begin{array}{l}\text { A transferable } \\
\text { technology }\end{array}$ & \multirow{4}{*}{$\begin{array}{l}\text { Energy efficiency and } \\
\text { eco friendliness: The } \\
\text { energy consumption in a } \\
\text { m3 can be from } 5 \text { to } 15 \\
\text { times less than a } \mathrm{m}^{3} \text { of } \\
\text { fired bricks. The pollution } \\
\text { emission will also be } 2.4 \\
\text { to } 7.8 \text { times less than } \\
\text { fired bricks }\end{array}$} \\
\hline $\begin{array}{c}\text { A job creation } \\
\text { opportunity }\end{array}$ & \\
\hline $\begin{array}{l}\text { Market opportunity: } \\
\text { Cheaper than fired } \\
\text { bricks }\end{array}$ & \\
\hline Reducing imports & \\
\hline
\end{tabular}

\section{K. Underground courtyard houses [Constructing case studies]}

The courtyard plan is best suited in flat terrain sites that have permeable, dry or well- drained soils which are far from a ground water source [27] With reference to the traditional underground building which is constructed in arid climatic regions. Some do not even require any supporting walls because of the land conditions [12]. This is the case in Egypt's desert. Underground courtyard type is represented in historic underground homes and there are fewer examples of contemporary ones. 
In the next table 4, some underground courtyard houses will be shown. They are classified according to the courtyard number in each house and its proportions.
Consequently, design guidelines will be deduced in order to help in constructing research case studies later.

Table 4. Sunken courtyard house examples and types

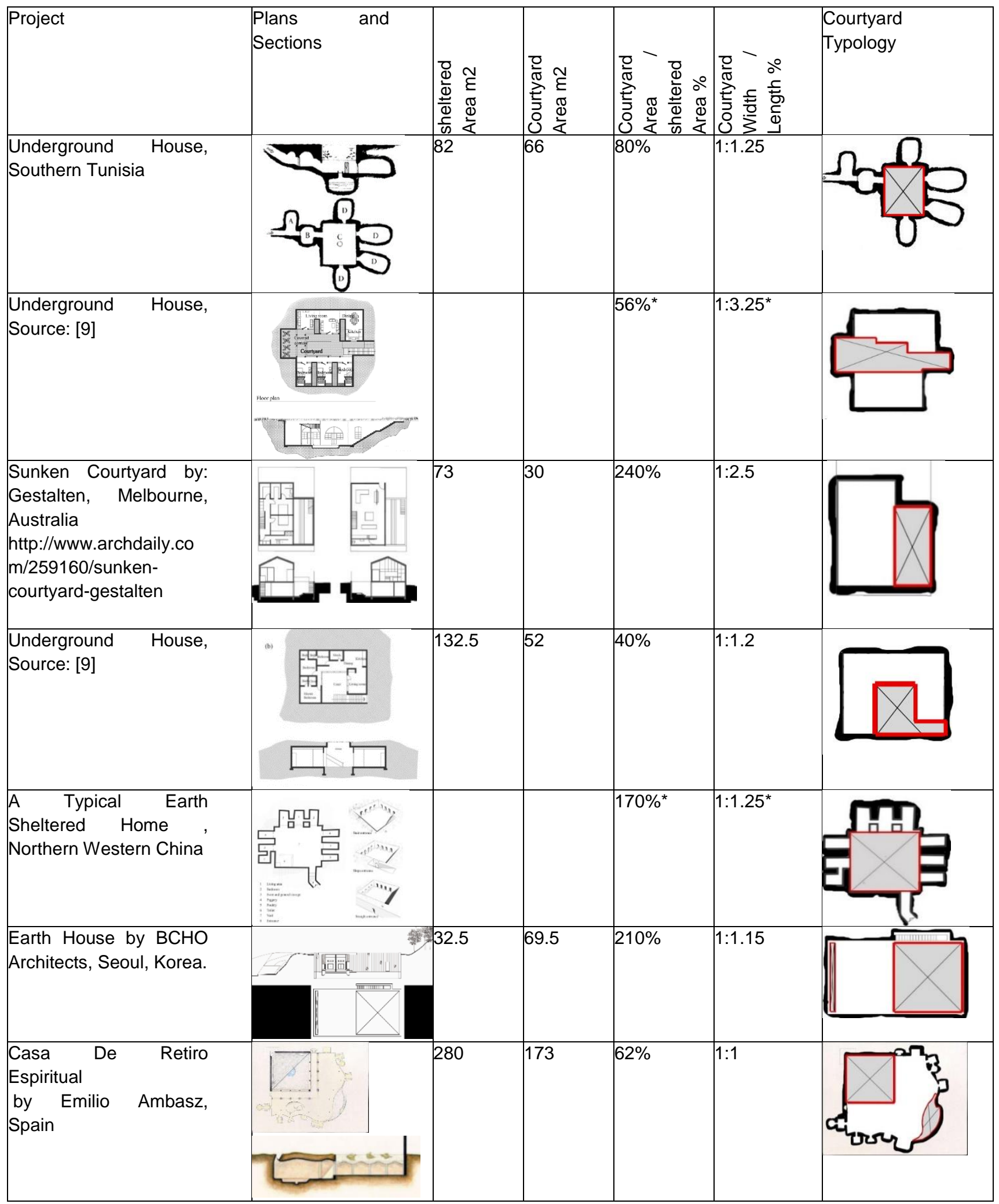




\begin{tabular}{|l|l|l|l|l|l|}
\hline Source: Unknown & & & & \\
\hline
\end{tabular}

From the scanning of habitable underground houses the researchers concluded that there are three courtyard types:

- One Square Courtyard type. (Recommended a 40m2 court for 80-120 m2 earth sheltered area)

- One Rectangle Courtyard type with aspect ratio 1:1.25.

- Multiple courtyards (two or three) with aspect ratio ranging from 1:1 to $1: 1.6$.

From the previous literature eight Residential building types were proposed taking into consideration the low cost Egyptian rustic dwellings' needs, with the following criteria:
- Low rise. (One or two floors). [In order to measure the influence of coupling the building with the ground on the thermal performance of the house]

- Have an internal court. (From literature: most appropriate for underground houses in desert climate).

- Low cost. (Rural house).

- (Area from 70 to $150 \mathrm{~m} 2$ + using local materials and local building roofing techniques such as domes and volts).

The researchers also authenticated the zero-level in all the eight cases due to building services issues.

Placing the building services at zero level to avoid using a sewage pump for sewage disposal, which represents a non-affordable cost for low cost houses. 


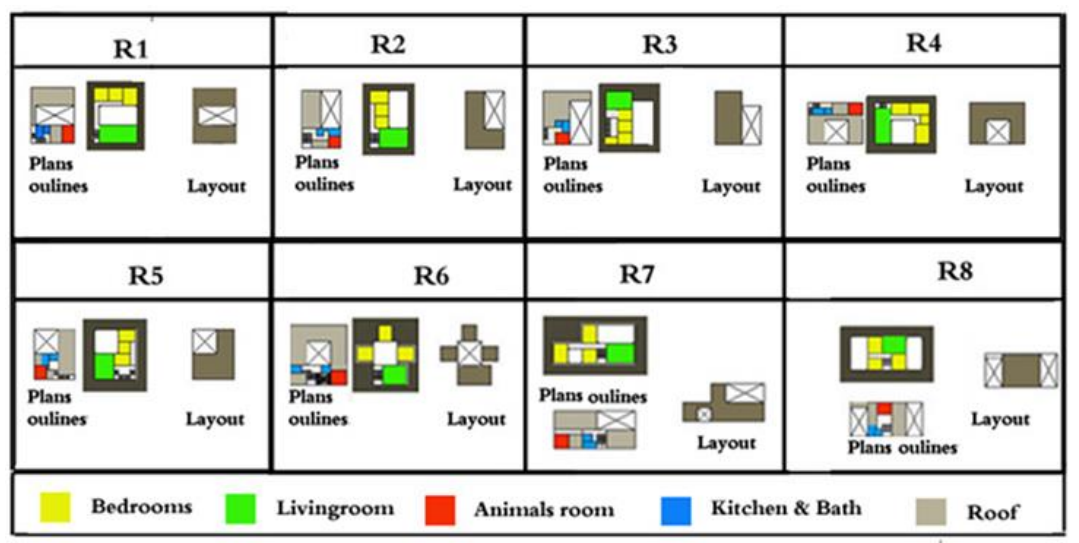

Fig. 6. Deduced eight types of courtyard houses which represent the case studies Source: Researchers.

\section{The principle of ground cooling by indirect contact:}

A long buried pipe - at a calculated depth for best efficiency - that have an end for fresh outside air intake and the other end for inside cooled air released in the building, this is the main idea of The Earth Pipe Cooling system. This system uses the ground as a heat sink for cooling in warm countries where the intake air, in the buried pipe, loses excess heat to the earth by convection. Adequate air flow into the buried pipe is a must to get cooled air for occupants' thermal comfort. A fan blower is needed at air intake if there is deficiency in air flow

\section{A. Factors that affect Earth Pipe Cooling performance}

As a conclusion from various published literature, the performance of Earth Pipe Cooling are affected by four main parameters and they are:

- Pipe length: A parametric study using different pipe lengths : $10 \mathrm{~m}, 30 \mathrm{~m}, 50 \mathrm{~m}, 70 \mathrm{~m}, 90 \mathrm{~m}$ concluded that the longer the pipe, the better the performance of the earth tube [28], [29].

- Pipe radius or diameter: The smaller the radius of the pipe the more decreased inlet temperature.

- Depth of the pipe inserted into the ground: As the pipe depth increases, the inlet air temperature decreases in all climate conditions [28].

- Air flow rate inside the pipe: as the air flow rate increases, the inlet air temperature increases [28],
[31] and the coefficient of performance (COP) reduces [32] (See Fig. 7).

Other factors that could affect the performance of Earth Pipe Cooling system is

- The surface condition of the ground: Bare or shaded.

- Soil type: sandy soil is much preferable than other soil types [33].

- The choice of pipe materials: different pipe materials have minor effects on the Earth Pipe Cooling system performance [34].

\section{B. Application of Earth Pipe Cooling}

Models of Earth to Air Heat Exchanger System (EAHE) made of low cost material like PVC pipes and exhaust fans

- a duct system suitable for small houses

- have been examined. Models show [35] temperature reduction of $10-15^{\circ} \mathrm{C}$ than outside during summer.

This system can effectively reduce the energy consumption between $50 \%$ and $60 \%$, which is consumed by building cooling (Air conditioning) and warming systems.

COP is a term used in refrigeration and air conditioning to describe the performance of a system. Normally, heating and air conditioning systems have average year-round COPs of about 2.0. The COPs of the systems utilizing underground air tunnels are much higher. For open and closed loop systems, the COP can be as high as 10 [33]. 
The higher the COP, the higher the efficiency of the equipment [29].

Table 5. Some Applications of Earth Pipe Cooling [29]

\begin{tabular}{|c|c|c|c|c|}
\hline Researcher & Location & Buried Pipe Design & Ambient T, ${ }^{\circ} \mathrm{C}$ & Energy Saving \\
\hline $\begin{array}{c}\text { Goswami and Biseli } \\
\text { (Summer, 1993) }\end{array}$ & Florida, USA & $\begin{array}{c}0.305 \mathrm{~m} \text { dia, } 30.5 \mathrm{~m} \text { long } \\
\text { pipe. } 2.7 \mathrm{~m} \text { deep. } \\
0.184 \mathrm{~kW} \text { fan blower and } \\
21 / 2 \text { ton heat pump }\end{array}$ & $\begin{array}{c}\text { Summer:23.9 }{ }^{\circ} \mathrm{C} \\
\text { to } 33.1^{\circ} \mathrm{C}\end{array}$ & $\begin{array}{c}\text { Open Loop COP }=12 \\
\text { COP (air-cond) }=1 \text { to } 4 \\
\text { With Heat Pump COP }= \\
13\end{array}$ \\
\hline Pfafferott (2003) & DB Netz AG & & & COP $=88$ \\
\cline { 2 - 5 } & Fraunhofer ISE & & COP $=29$ \\
\cline { 2 - 5 } & Lamparter & & COP $=380$ \\
\hline
\end{tabular}

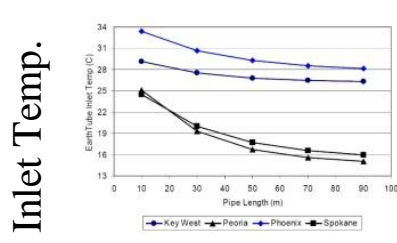

Pipe length

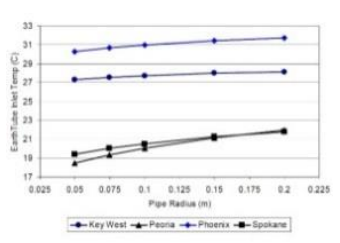

Pipe radius

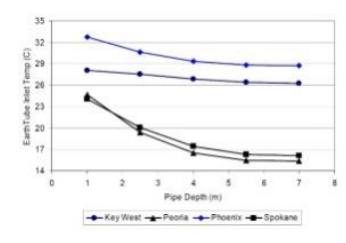

Depth of the pipe

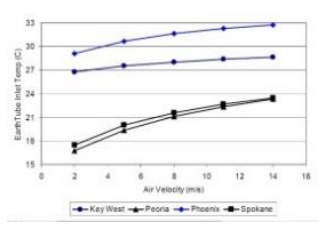

Air flow rate

Fig. 7. Factors that affect Earth Pipe Cooling performance [28]

\section{Limitations}

The risk of condensation in the buried pipe: to avoid his problem the pipe may be tilted slightly to allow the water condensed to drain away through a tiny hole [30], [37]. This is a preference to the arid climate of Egypt.

\section{Hybrid design for enhancement of ground cooling system}

Maerefat and Poshtiri introduced and investigated integrated EAHE-SC system. They showed that the solar chimney can be perfectly used to power the underground cooling system during the daytime, without any need for electricity [39].

The air is heated up in the SC by the solar energy, and by natural convection mechanism the outside air is sucked-in through the earth-air pipe.

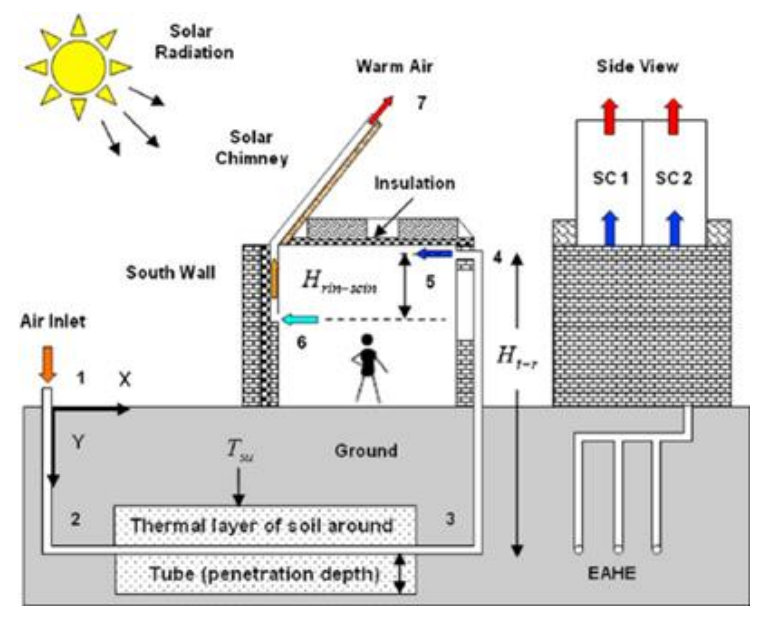

Fig. 8: Schematic diagram of integrated earth to air heat exchanger and solar chimney (Maerefat, M., Poshtiri, A., 2010)

Poshtiri, et al., [40] examined SC-EAHE system. The results show that proper configurations could provide good indoor condition even at poor solar intensity of $100 \mathrm{~W} / \mathrm{m} 2$ and high ambient air temperature of $50^{\circ} \mathrm{C}$. Comparative survey shows the SC-EAHE system is the best choice for buildings with poor insulation at day time.

Hammadi and Mohammed investigated the Solar Chimney (SC) together with earth to air heat exchanger (EAHE) as a low-energy consuming technique. A numerical program "FLUENT 6.3 code" of an earth to air heat exchanger (EAHE) was used for predicting the outlet air temperature and cooling 
potential of these devices in Basrah climate which is hot arid. Theoretical analyses have been conducted to investigate the ventilation in a solar chimney [41].

The results have shown significant temperature reductions at the buried pipe outlets from their inlets. Maximum temperature drop through the buried pipe was found to be $11^{\circ} \mathrm{C}$. In both seasons. The performance of the buried pipe increases with increasing pipe length only up to $70 \mathrm{~m}$ and with small pipe diameters and the best velocity is $1 \mathrm{~m} / \mathrm{s}$.

\section{E. Geothermal energy researches in Egypt}

Hassan and El-Moghasy, carried their field experiments using air as the working fluid in a pipe-air cooler. The results showed a reduction of the air temperature of about $12^{\circ} \mathrm{C}$ when it flowed for $50 \mathrm{~m}$ of the pipe-air cooler when the inlet air temperature and relative humidity of 35 , and $30 \%$, respectively [42].

Ali, M. investigated experimentally the effect of the layout of the horizontal ground heat exchanger - using water instead of air - from being straight or spiral [43]. The results showed that the effect of depth of the amount of heat extracted by the straight heat exchanger is weak when compared with that of the entering water temperature; both of the previous works were laboratory based ones. The real systems did not exist and it is required to have further research in which the real circumstances and actual systems are utilized.

\section{Computer Modelling}

A wide range of scientifically validated Building Performance Simulation tools BPS is available internationally. Attia mentioned ten major BPS tools: ECOTECT, HEED, Energy 10, Design Builder, eQUEST, DOE-2, Green Building Studio, IES VE, Energy Plus and Energy Plus-Sketch Up Plugin (Open Studio) [25].

Energy Plus which will be used as a simulation tool in this research was developed based on two existing programs: DOE-2 and BLAST. It includes a number of innovative simulation features [26].

\section{Soil Temperatures}

It is essential when researching the earth sheltered buildings or the (EAHE) system to calculate the ground temperature of the location because it strongly affects the performance of these systems. [38]
Heat transfer in soils is governed by a number of variables which tend to fluctuate according to the changes in moisture content and other soil texture, structure and composition parameters.

Several mathematical models were developed to evaluate the temperature of the ground, such as those of Morland, Kusuda, and Labs [45]. Their models present a solution of the equation of heat transfer of a semi-infinite solid whose variation in the external temperature is sinusoidal.

Moustafa et al, Ben Jmaa and Kanoun, Al-Ajmi et al., Sharan and Jadhav, Ogunlela, Mihalakakou et al, AlTemeemi A., and Harris D.J., Gouda, A., Nofziger, D. all worked to develop an empirical model for the prediction of soil temperature as a function of soil depth and time of the year and generate a subsurface temperature profile for various locations around the world using Labs equation [11], [32], [44-51].

To evaluate the temperature of the ground, the soil is regarded as a semi-infinite solid. It is expressed according to the depth and time. Labs equation predicts the long-term annual pattern of soil temperature variations as a function of depth and time for various soil properties.

$$
T_{(x, t)}=T_{m}-A_{s} e^{-x \sqrt{x / 365 \alpha}} \cos \left\{\frac{2 \pi}{365}\left[t-t_{0}\left(\frac{x}{2}\right)\left(\sqrt{\frac{365}{\pi \alpha}}\right)\right]\right\}
$$

Table 6: Lab's Equation variables: [11]

\begin{tabular}{|c|c|}
\hline$T(x, t)$ & $\begin{array}{l}\text { Temperature of soil at depth } \mathrm{x} \text { and on day } \mathrm{t} \text { of the year } \\
\qquad\left({ }^{\circ} \mathrm{C}\right)\end{array}$ \\
\hline$x$ & Depth below surface [m] \\
\hline$t$ & time of year in days $(\operatorname{Jan} 1=1)$ \\
\hline $\mathrm{Tm}$ & $\begin{array}{c}\text { Mean annual ground surface temperature }\left({ }^{\circ} \mathrm{C}\right) \text { [adding } \\
1.7 \text { to the average annual air temperature]. }\end{array}$ \\
\hline to & $\begin{array}{l}\text { The phase constant, [corresponding to the day of } \\
\text { minimum surface temperature (days) The phase of the } \\
\text { solar radiation wave lags behind the cyclic wave of the } \\
\text { surface temperature by } 1 / 8 \text { of a cycle or } 46 \text { days]. }\end{array}$ \\
\hline As & $\begin{array}{c}\text { Amplitude of surface temperature wave } \\
\left({ }^{\circ} \mathrm{C}\right) . \text { [adding half of the difference between July and } \\
\text { January average monthly air temperatures }+1.1^{\circ} \mathrm{C} \text { ] }\end{array}$ \\
\hline e & Euler's number ( constant) $=2.71828$ \\
\hline$\alpha$ & $\begin{array}{l}\text { The thermal diffusivity of the soil (m2/day) [by dividing } \\
\mathrm{K} \text { (conductivity w/mk) over [p (soil density kg/m3) } \\
\text { multiplied by c (specific heat } \mathrm{J} / \mathrm{kgk})] \text {. [ } \alpha=\mathrm{K} / \mathrm{pc}][11] \text {. }\end{array}$ \\
\hline
\end{tabular}




\section{METHODOLOGY}

For the proposed eight residential types [R1-R2......R8] (See fig. 6), a one zone building [The house can be considered as one zone due to assumed sufficiently uniform thermal conditions, Source: ISO 52000-1:2017] will be simulated using Energy plus/Design Building program to measure: yearly discomfort hours for unconditioned cases and energy consumption assumed condition cases, as follows:

\section{Design Variables:}

- Location template, two options of the cities' weather files inputs (Aswan and Ismailia).

- Orientation: $0^{\circ}-$ and $90^{\circ}$.

- Building level: with two options: Above ground or underground.

- Earth Air Tubes: with two options: Yes or No.

For each specific building type and orientation there are four plans or (arrangements):

1- (PO): Above ground.

2- PA): Aboveground + EAHE.

3- (PB): Underground with $0.50 \mathrm{~m}$ earth layer above it

4- $(P C)$ : Underground + EAHE.

\section{Building Specifications:}

Occupancy density (m2/pp.) Number of floors Height per floor $20 \mathrm{~m} 2 / \mathrm{pp}$

Table 7: Openings \& R values: (According to the Egyptian Energy Efficiency Code for buildings)

\begin{tabular}{|c|c|c|}
\hline Elevation & WWR & R value \\
\hline North & $\leq 30 \%$ & 1.00 \\
\hline East \& West & $\leq 20 \%$ & 1.3 \\
\hline South & $20-30 \%$ & 1.00 \\
\hline
\end{tabular}

Table 8: Building Activity Options, assumed

\begin{tabular}{|c|c|}
\hline Activity & Domestic Lounge \\
\hline Density & $0.08 \mathrm{p} / \mathrm{m} 2$ \\
\hline Heating set point temp. & 21 \\
\hline Heating setback temp. & 12 \\
\hline Cooling set point temp. & 25 \\
\hline Cooling setback temp. & 28 \\
\hline Target Illuminance (Lux) & 150 \\
\hline Computer \& Cattering & On \\
\hline
\end{tabular}

Table 9: Building Assemblies, assumed

\begin{tabular}{|c|c|}
\hline \multicolumn{2}{|c|}{ Above Ground Walls } \\
\hline Cement plaster & $.025 \mathrm{~m}$ \\
\hline Brick burned & $0.12 \mathrm{~m}$ \\
\hline Cement plaster & $.025 \mathrm{~m}$ \\
\hline \multicolumn{2}{|c|}{ U Value : $2.6 \mathrm{~W} / \mathrm{m} 2 \mathrm{~K}$} \\
\hline \multicolumn{2}{|c|}{ Underground Walls } \\
\hline $\begin{array}{l}\text { Compressed cement stabilized } \\
\text { Earth blocks (CSEB). } 5 \% \text { cement. }\end{array}$ & $0.12 m$ \\
\hline Bitumen pure & $0.025 \mathrm{~m}$ \\
\hline $\begin{array}{l}\text { Compressed cement stabilized } \\
\text { Earth blocks (CSEB). } 5 \% \text { cement. }\end{array}$ & $0.05 \mathrm{~m}$ \\
\hline Cement plaster & $0.025 \mathrm{~m}$ \\
\hline \multicolumn{2}{|c|}{ U Value : $0.76 \mathrm{~W} / \mathrm{m} 2 \mathrm{~K}$} \\
\hline \multicolumn{2}{|c|}{ Above Ground Building Floors } \\
\hline Concrete tiles & $0.02 \mathrm{~m}$ \\
\hline Cement plaster & $0.025 \mathrm{~m}$ \\
\hline Sand and gravel & $0.05 \mathrm{~m}$ \\
\hline Reinforced concrete & $0.12 \mathrm{~m}$ \\
\hline Gypsum plaster & $0.025 \mathrm{~m}$ \\
\hline \multicolumn{2}{|c|}{ U Value : $3.13 \mathrm{~W} / \mathrm{m} 2 \mathrm{~K}$} \\
\hline \multicolumn{2}{|c|}{ Above Ground Building Roofs } \\
\hline Plaster ceiling tiles & $0.02 m$ \\
\hline Sand and gravel & $0.05 \mathrm{~m}$ \\
\hline Cast concrete & $0.075 \mathrm{~m}$ \\
\hline Bitumine & $0.02 \mathrm{~m}$ \\
\hline (CSEB). $5 \%$ cement. & $0.14 \mathrm{~m}$ \\
\hline Gypsum plaster & $0.025 \mathrm{~m}$ \\
\hline \multicolumn{2}{|c|}{ U Value : $1.38 \mathrm{~W} / \mathrm{m} 2 \mathrm{~K}$} \\
\hline
\end{tabular}

Note: Bottom and vertical boundary conditions were set at the edges of a domain $15 \mathrm{~m}$ under a slab and next to the walls. It follows the hints of the European Standard EN ISO 13370 "Thermal performance of buildings - Heat transfer via the ground - Calculation methods". 
Table 10. Used Building Material

\begin{tabular}{|c|c|c|c|c|c|}
\hline Used Building Material & Walls & Roofs & $\begin{array}{c}\lambda \text { (Coefficient of } \\
\text { conductivity) }\end{array}$ & $\begin{array}{c}\text { Compression } \\
\text { strength }\end{array}$ & $\begin{array}{c}\text { Tensile } \\
\text { strength }\end{array}$ \\
\hline $\begin{array}{c}\text { Compressed Cement } \\
\text { Stabilized Earth Blocks } \\
\text { (CSEB).5\% cement. }\end{array}$ & $\begin{array}{c}24^{\star} 24^{*} 13 \\
\mathrm{~cm} \\
\text { blocks }\end{array}$ & $\begin{array}{c}14^{\star} 7^{*} 7 \mathrm{~cm} \text { blocks } \\
\text { for domes and } \\
\text { vaults. }\end{array}$ & $0.65 \mathrm{~W} / \mathrm{m}^{\circ} \mathrm{C}$ & $6 \mathrm{Mpa}$ & $1.5 \mathrm{Mpa}$ \\
\hline \multicolumn{3}{|c|}{ Notes Source: [52] } & $1 \mathrm{Mpa}=10 \mathrm{Kg} / \mathrm{cm} 2$ \\
\hline
\end{tabular}

Table 11. Glazing Type, assumed

\begin{tabular}{|c|c|c|c|c|c|c|c|}
\hline Window Type & Blends & WWR & Window Height & Still Height & Window Spacing & Frame & $\begin{array}{c}\text { SHGC and } \\
\text { SGR }\end{array}$ \\
\hline $\begin{array}{c}\text { Single Clear } \\
0.006 \mathrm{~m} \text { Glazing }\end{array}$ & $\begin{array}{c}\text { internal } \\
\text { blends }\end{array}$ & $30 \%$ & $1.50 \mathrm{~m}$ & 0.80 & 5.00 & $\begin{array}{c}\text { Painted } \\
\text { Wooden }\end{array}$ & don't count \\
\hline
\end{tabular}

\section{EAHE simulation inputs}

Table 12. Variables of EAHE System, assumed.

\begin{tabular}{|c|c|}
\hline Values & Schedule Name \\
\hline Fan Blower 24 hours & Design flow rate \\
\hline $0.0334 \mathrm{~m} 3 / \mathrm{s}$ & Min. Zone temp. when cooling \\
\hline $200 \mathrm{C}$ & Max. zone temp. when \\
heating
\end{tabular}

\section{RESULTS}

\section{Underground and Air Temperatures}

Using Labs' equation underground temperatures were calculated for the whole year for depths $(0.5 \mathrm{~m}, 2 \mathrm{~m}$, and $4 \mathrm{~m}$ ) which is very important for subsurface buildings simulations.

Max Av. Air Temp. in Aswan reaches $42^{\circ} \mathrm{C}$ in June while Min. Av. descends to $10^{\circ} \mathrm{C}$ in January with $32^{\circ} \mathrm{C}$ range. While at depth $4 \mathrm{~m}$ Temp. ranges from $25^{\circ} \mathrm{C}$ and $29.8^{\circ} \mathrm{C}$ with only $4.8^{\circ} \mathrm{C}$ range. In Ismailia this range is also only $4^{\circ} \mathrm{C}$.

Table 13. Variable Used for Aswan Soil Temp. Calculation

\begin{tabular}{|c|c|}
\hline Variables & Calculated values for Aswan \\
\hline Tm & $27.45^{\circ} \mathrm{C}$ \\
\hline As & $10.6^{\circ} \mathrm{C}$. \\
\hline $\mathrm{t} 0$ & Day 36. \\
\hline$\alpha$ & 0.064 \\
\hline
\end{tabular}

Table 14. Variable Used for Ismailia Soil Temp. Calculation

\begin{tabular}{|c|c|}
\hline Variables & Calculated values for Ismailia \\
\hline $\mathrm{Tm}$ & $23.18^{\circ} \mathrm{C}$ \\
\hline As & $8.96^{\circ} \mathrm{C}$. \\
\hline t0 & Day 65. \\
\hline$\alpha$ & 0.064 \\
\hline
\end{tabular}




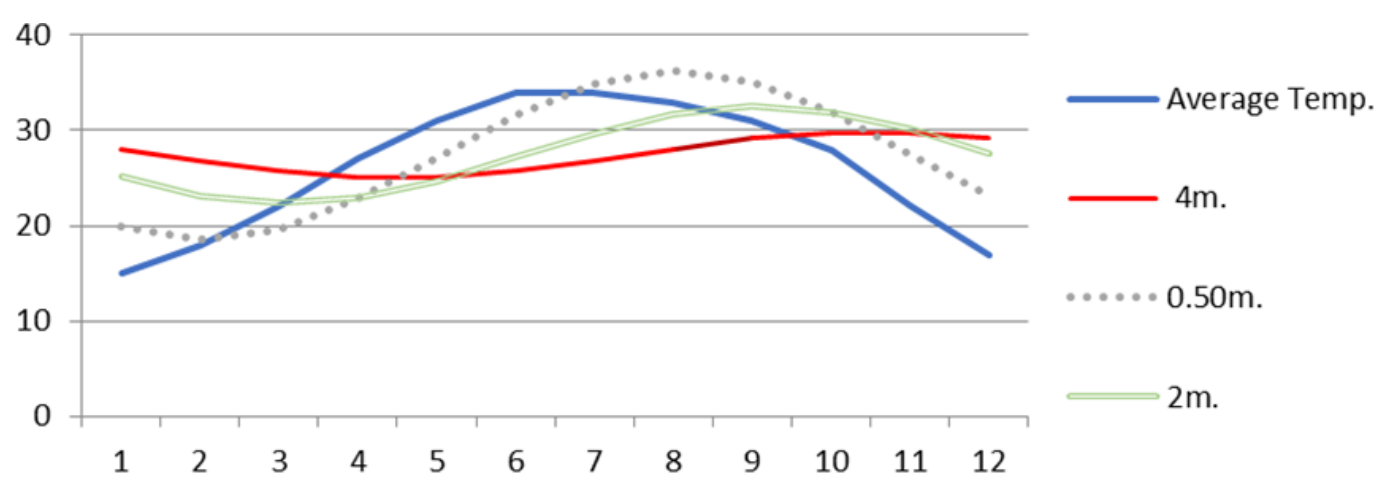

Fig.10. Average monthly temp. compared to calculated soil temp.in Aswan Source : Researchers

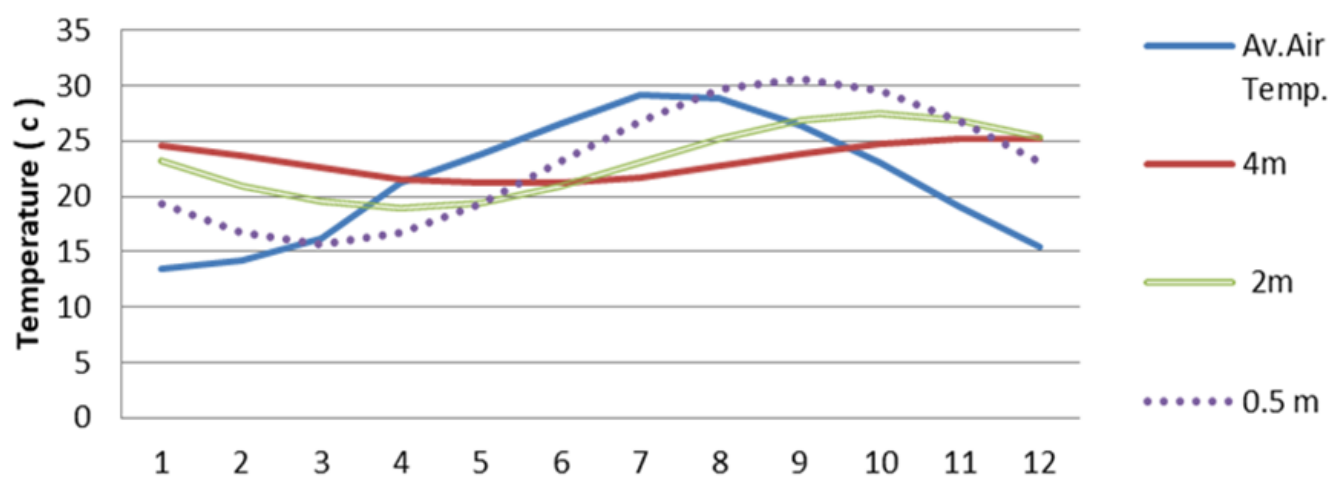

Fig. 11: Average monthly temp. compared to calculated soil temp.in Ismailia Source : Researchers

\section{Thermal Comfort Analysis and Comparisons}

Thermal comfort was monitored in simulated eight types (R1....R8) - two orientations each - per each of the four plans or (arrangements): PO, PA, PB, PC by calculating yearly discomfort hours as an indication for thermal comfort as there is counter relation between discomfort hours and thermal comfort.

Yearly Discomfort Hours reached 2193h in above building base case in Aswan [plan (PO) for Type R6] and Min. of $1291 \mathrm{~h}$ in [plan (PC) for Type 3] which is an underground building with a EAHE. In Ismailia
Yearly Discomfort Hours reached $2351 \mathrm{~h}$ in plan (PB) (underground building for type R6) and Min. of 850h in [plan (PC) for (Type3)], which is an underground building with an EAHE.

In both Aswan and Ismailia: the average readings point out that above ground (PO) are the highest discomfort hours, while underground with EAHE are the least. Meanwhile underground (PB) in Ismailia showed rise in discomfort hours due the time lag which needs further research and simulation (See fig. 12).
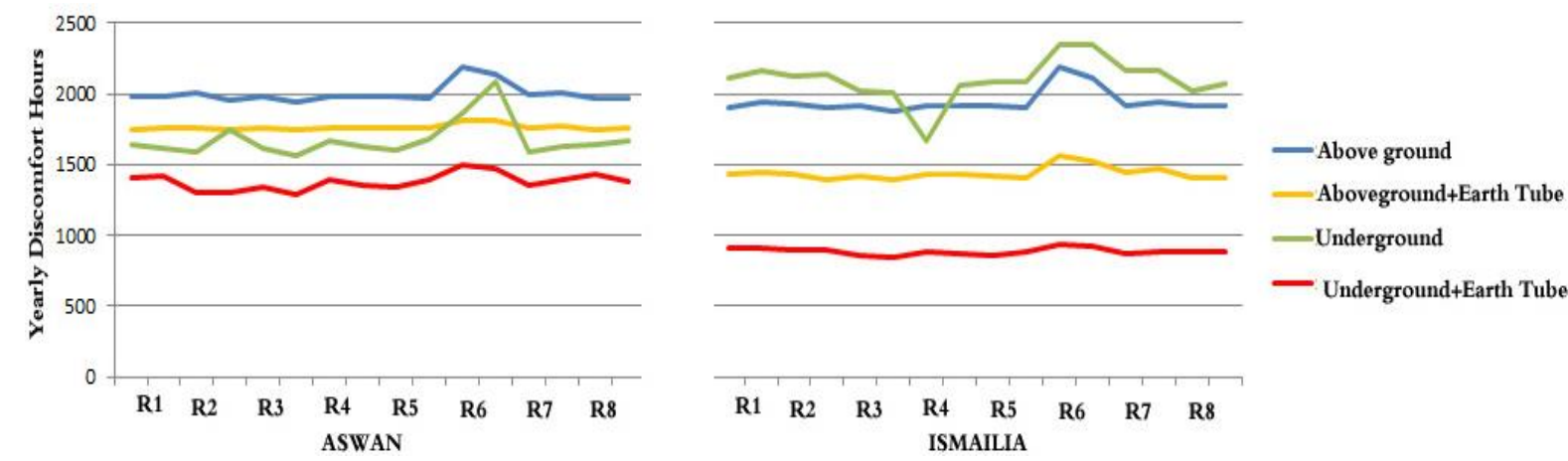

Fig. 12. Yearly discomfort hours [ Measured for the four plans(arrangements): (O-A-B-C)] Source: Researchers 


\section{Energy Consumption}

Was monitored in simulated eight types (R1...R8) two orientations each - per two plans or (arrangements): Plan PO [aboveground building with common building specification in new urban settlements in Egypt] and plan PB [Underground building with proposed (CSEB). $5 \%$ cement construction], both plans were assumed to be full conditioned in order to be able to calculate energy consumption to reach comfort conditions.
Energy consumption reached $343 \mathrm{KWh} / \mathrm{m} 2$ in the above building base case (R6 type-d2) in Aswan and Min. of $104 \mathrm{KWh} / \mathrm{m} 2$ in plan (PB) (R3 type-d2). In Ismailia Yearly Energy Consumption $187.5 \mathrm{KWh} / \mathrm{m} 2$ in above building base case (R6 type-d2) and reached $42 \mathrm{KWh} / \mathrm{m} 2$ in plan (PB) (R3 type-d2).

Note: All calculations were made for both building directions 0 \& 90 for each eight building types for each city climate with a total of 96 readings.
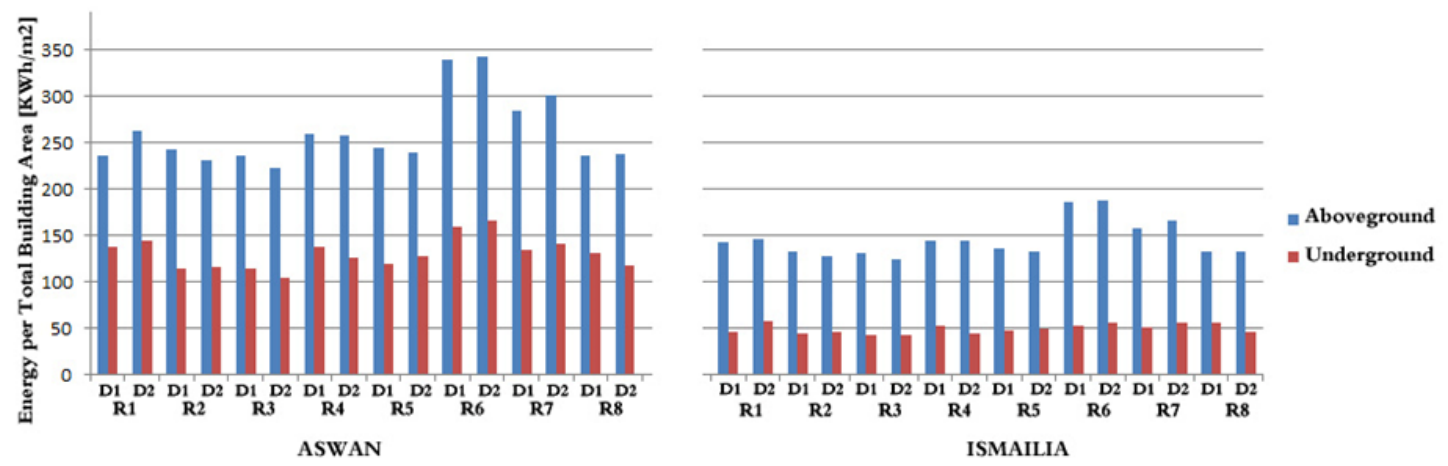

Fig. 13. Energy consumption to reach thermal comfort [Measured for the two plans: [P (O- B)]. Source: Researchers

\section{DISCUSSION AND CONCLUSION}

- As mentioned before, calculated underground temperatures for both Aswan \& Ismailia showed a sinusoidal behavior and the cyclical temperature wave that becomes more flat with the increases in depth. Ismailia has more time lag (65 days) than Aswan (36 days).

- For all eight types R1-R8, and two building orientations D1\& D2 the researchers can conclude that:

- In Aswan Discomfort hours decrease between $28 \%$ and $34 \%$ in the above ground building plan (PO) compared to the underground building with an EAHE plan (PC), while energy consumption decreases between $42 \%$ and $53 \%$ for the previous comparison.

- In Ismailia Discomfort hours decrease between $24 \%$ and $29 \%$ between the above ground building plan (PO) and the underground building with a EAHE plan (PC), while energy consumption decreases between $57 \%$ and $72 \%$ for the previous comparison.
In plan [arrangement (PB) (underground without EAHE)], it is noticed that discomfort hours are the highest although there is less energy needed to achieve thermal comfort (See. Fig. 13). This may be due to long time lag, which indicates that the earth keeps and loses the heat delayed 65 days than aboveground ambient air, which causes more discomfort hours while the standard deviation in temperature differentiation between aboveground and underground is small so that energy needed to achieve comfort is still low. (So further investigations on other climate regions within Egypt are needed to prove these assumptions).

\section{CONCLUSION}

- The research concludes that earth-sheltered courtyard house constructed using CSEB and combined with an EAHE system is one of the promising passive solutions for saving energy in desert houses in Egypt.

- Energy consumption in Ismailia is more than in Aswan due to the higher time lag between ground temperature and air temperature. 
- Best case for Aswan with maximum decrease in both discomfort hours and energy consumption is $\mathrm{R} 3 / \mathrm{D} 2$, which is the max in the compacted plan.
- Ismailia's best case is R6/D1, which has the max. area contact with earth.

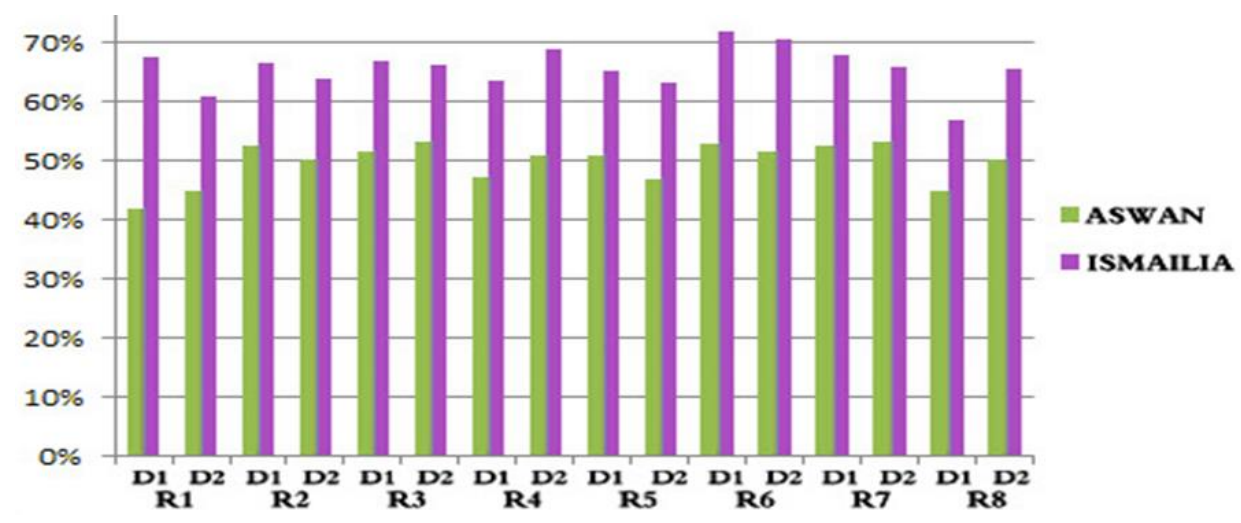

Fig. 14: \% Decrease in energy consumption (\% Difference between plan PO\& PB) for the two directions of the eight types. Source: Researchers

\section{RESEARCH RECOMMENDATIONS}

Taking into account the arid climate, the dry soil, the deep ground water levels of Egypt's desert and the need for low cost energy efficient housing; a design proposal is presented according to the research:

- Locating the building underground level with 0.50 $\mathrm{m}$ earth layer above it, (This protects the roof from direct solar radiation while decreasing the dead loads on the roof).

- Using sunken courtyard about $40 \mathrm{~m}^{2}$ with buried area $80-120 \mathrm{~m}^{2}$ to provide ventilation, light, solar heat, outside views, and access via a stairway from the ground level.

- The research recommends stabilized earth blocks as a sustainable low cost material that also helps to reuse the excavated soil resulted from basements with dome and vaults for roofing.

- Locating the service area above ground level can avoid using pumps for sewage.

- Using an (EAHE) system with cheap irrigation tubes placed in the building foundations or on the underground bearing walls will be cost effective because the digging cost will be avoided as the basement was already dug.

- The soil surface to be shaded or vegetated to obtain cooler soil temperature for better energy performance.
- Calculating ground temperatures - using Labs' equation- is essential when modeling the efficiency of the underground house.

- Compact underground building is more effective in Aswan, while more building earth contacted areas is more efficient in Ismailia.

- Future detailed studies for more cities with different weathers in Egypt are recommended.

- Further structural, economical, architectural refinements and users' acceptance studies for the suggested building types are recommended.

- The researchers recommend further studies on integrating SC with EAHE system in earth sheltered homes.

\section{REFERENCES}

[1] H. Farrouh, H. and A Lubna. "Passive and hybrid techniques for low cost energy efficient housing in hot dry climate," Azhar University Magazine, Egypt, vol. 11, no. 41, pp. 1265-1274, 2016.

[2] The Egyptian Electricity Holding Company Annual Report 2009/2010, Egyptian Electricity Holding Company, Cairo, Egypt, 2010, pp. 1-48.

[3] M. Ali . "Modelling the performance of horizontal heat exchanger of ground-coupled heat pump 
systems with Egyptian conditions," University Of Manchester, 2013.

[4] M.G. Salim. "Selection of groundwater sites in Egypt, using geographic information systems, for desalination by solar energy in order to reduce greenhouse gases," Journal of Advanced Research, vol. 3, no. 1, pp. 11-19, 2012

[5] D. Banks. An Introduction to Thermogeology: Ground Source Heating and Cooling. WileyBlackwell, 2012.

[6] A.J. Anselm. "Passive annual heat storage principles in earth sheltered housing, a supplementary energy saving system in residential housing," Energy and Buildings, vol. 40, no. 7 pp. 1214-1219, 2008.

[7] B. Hoyle. Low Energy Building Engineering. $1^{\text {st }}$ ed., The English Press, 2011, pp. 114-125.

[8] B. Rudofsky. Architecture Without Architects. Doubleday \& Company, 1964.

[9] A. Jideofor, . "Earth shelters; A review of energy conservation properties in Earth sheltered housing," Energy Conservation, pp.127, 2012

[10] C. von Dronkelaar. Underground Buildings. Thesis / University Of Technology Eindhoven, 2013.

[11] A.A. Al-Temeemi, and D.J Harris. "The generation of subsurface temperature profiles for Kuwait," Energy and Buildings, vol. 33, no. 8, pp. 837-841, 2001

[12] A.S. Alkaff, et al. "A review of underground building towards thermal energy efficiency and sustainable development," Renewable and Sustainable Energy Reviews, vol. 60, pp. 692713, 2016.

[13] S. Baggs , at al. "Australian earth-covered building," NSW University Press, 1991, Kensington.

[14] A.A. Al-Temeemi and D.J. Harris. "A guideline for assessing the suitability of earth-sheltered mass-housing in hot-arid climates," Energy and Buildings, vol. 36, no. 3, pp. 251-260, 2004.
[15] R. A. Behr. Suitable Thin Shell Structural Configurations for Earth Sheltered Housing. PhD. Thesis, Texas Tech University, 1982.

[16] P. Carpenter. "Sod It': an introduction to earth sheltered development in England and Wales," British Earth Sheltering Association, "Sod It": an Introduction to Earth Sheltered Development in England and Wales, 1994.

[17] T.A. Bligh. "Comparison of energy consumption in earth covered vs. non-earth covered buildings," in Proceedings of the Conference on Alternatives in Energy Conservation, National Science Foundation, 1975.

[18] G. Golany. Earth-Sheltered Habitat: History, Architecture and Urban Design. Van Nostrand, 1983.

[19] A.A. Al-Mumin. "Suitability of sunken courtyards in the desert climate of Kuwait," Energy and Buildings, vol. 33, no. 2, pp. 103-111, 2001.

[20] National Renewable Energy Laboratory (Nrel). "Earth-sheltered houses," Energy Efficiency and Renewable Energy Clearinghouse, 1997.

[21] H. Wallbaum, et al. "Indicator based sustainability assessment tool for affordable housing construction technologies," Ecological Indicators, vol. 18, pp. 353-364, 2012.

[22] T. Akmal, , et al. "Rice-straw based cement brick microclimatic thermal impact assessment in Cairo, Egypt," Proceedings of the World Renewable Energy Congress â Sweden, 8â 13 May, 2011, LinkÃ PPing, Sweden, 2011.

[23] M. El-Kabbany. Alternative Building Materials and Components for Affordable Housing in Egypt: Towards Improved Competitiveness of Modern Earth Construction, MSc. Thesis, Ain Shams University, Egypt, 2013.

[24] A.M. Bauchard, ed. "Compressed stabilized earth blocks," Auroville Earth Institute Newsletter, pp.3 2012.

[25] S. Attia, et al. "Architect friendly: A comparison of ten different building performance simulation tools," $11^{\text {th }}$ IBPSA Building Simulation Conference. Glasgow, Scotland, 2009. 
[26] D.B. Crawley, et al. "Energy plus: Creating a new-generation building energy simulation program," Energy and Buildings, vol. 33, no. 4, pp. 319-331, 2001.

[27] A.A. Al-Temeemi and D.J. Harris. "The effect of earth-contact on heat transfer through a wall in Kuwait," Energy and Buildings, vol. 35, no. 4, pp. 399-404, 2003.

[28] K.H. Lee and R. Strand. "Implementation of an earth tube system into energy plus program," Energy and Buildings, vol. 40, 2006.

[29] A. Sansui. "Low energy ground cooling system for buildings in hot and humid Malaysia," De Montfort University, Malaysia, 2012.

[30] M. Santamouris, et al. "Use of buried pipes for energy conservation in cooling of agricultural greenhouses," Solar Energy, vol. 55, no. 2, pp. 111-124, 1995.

[31] V. Bansal and J. Mathur "Performance enhancement of earth air tunnel heat exchanger using evaporative cooling," International Journal of Low-Carbon Technologies, vol. 4, pp 150158, 2009.

[32] G. Mihalakakou, et al. "Parametric prediction of the buried pipes cooling potential for passive cooling applications," Solar Energy, vol. 55, pp. 151-234, 1995.

[33] A.K. Misra, et al. "Design and performance evaluation of low cost earth to air heat exchanger model suitable for small buildings in arid and semi-arid regions," KSCE Journal of Civil Engineering, vol. 19, no. 4, pp. 853-856, 2014.

[34] D.Y. Goswami and K.M. Biseli. Use of Underground Air Tunnels for Heating and Cooling Agricultural and Residential Buildings. Fact Sheet EES 78, pp. 1-4., Florida Energy Extension Service, University Of Florida, 1993. infohouse.p2ric.org/ref/08/07683.pdf\&p=DevEx, 5066.1 .

[35] T. Choudhury and A.K. Misra. "Minimizing changing climate impact on buildings using easily and economically feasible earth to air heat exchanger technique," Mitigation and Adaptation
Strategies for Global Change, vol. 19, no. 7, pp. 947-954, 2013.

[36] J. Pfafferott. "Evaluation of earth-to-air heat exchangers with a standardised method to calculate energy efficiency," Energy and Buildings, vol. 35, no. 10, pp. 971-983, 2003.

[37] N.M. Thanu, et al. "An experimental study of the thermal performance of an earth-air-pipe system in single pass mode," Solar Energy, vol. 71, no. 6, pp. 353-364, 2001.

[38] M.D. Paepe and A. Janssens. "Thermohydraulic design of earth-air heat exchangers," Energy and Buildings, vol. 35, no. 4, pp. 389397, 2003.

[39] M. Maerefat and A.P. Haghighi. "Passive cooling of buildings by using integrated earth to air heat exchanger and solar chimney," Renewable Energy, vol. 35, no. 10, pp. 2316-2324, 2010.

[40] A.H. Poshtiri, et al. "Feasibility study on using solar chimney and earth-to-air heat exchanger for natural heating of buildings," Proceedings of the World Renewable Energy Congress â Sweden, 8â13 May, 2011, LinkÃPing, Sweden, 2011.

[41] H. Hammadi, and A. Mohammed. "Application of earth tube heat exchanger and solar chimney for natural cooling system in Basrah City," Journal for Engineering Sciences, pp. 23-32, 2014.

[42] M.S. Hassan and I.M. El-Moghasy. "Space conditioning by pipe-air cooler buried in earth," First Conference of the Egyptian Combustion Society, 1989.

[43] M.O. Ali. "Development of design factors for spiral ground heat exchanger in heat pump applications," Al-Minia University, Al-Minia University, 2005, p. 29.

[44] S. Moustafa, et al. "Arid soil temperature model," Solar Energy, vol. 27, no. 1, pp. 83-88, 1981.

[45] M. Derradji and M. Aiche. "Modeling the soil surface temperature for natural cooling of buildings in hot climates," Procedia Computer Science, vol. 32, pp. 615-621, 2014. 
[46] H.B.J. Derbel and O. Kanoun. "Investigation of the ground thermal potential in Tunisia focused towards heating and cooling applications," Applied Thermal Engineering, vol. 30, no. 10, pp. 1091-1100, 2010.

[47] F. Al-Ajmi, et al. "The cooling potential of Earthâ€air heat exchangers for domestic buildings in a desert climate," Building and Environment, vol. 41, no. 3, pp. 235-244, 2006.

[48] Sharan, et al. "Soil Temperatures Regime at Ahmedabad." EconPapers, 2 Nov. 2002, econpapers.repec.org/RePEc:iim:iimawp:wp000 50 .

[49] A.O. Ogunlela. "Modeling soil temperature variations," Journal of Agricultural Research and Development, vol. 2, no. 1, pp. 100-109, 2009.

[50] A. Gouda. "Using of geothermal energy in heating and cooling of agricultural structures," Benha University, 2010.

[51] D.L. Nofzigerd. "Soil temperature changes with time and depth theory." Http://Soilphysics.Okstate.Edu/Software/Soiltem perature/Document.Pdf, 2003.

[52] Editor in chief: A.M. Bauchard. "Compressed stabilized earth blocks," Auroville Earth Institute, India, 2012.

\section{- List of Figures}

Fig.1: Egyptian electricity consumption (most consuming) is the residential. The Egyptian Electricity Holding Company Annual Report 2009/2010. Egyptian Electricity Holding Company, Cairo, Egypt, 2010.

Fig.2: Classification of aquifer depth in Egypt. Source: M. Salim, Selection of Groundwater Sites in Egypt. Journal of Advanced Research, 2012.

Fig.3: Earth's energy budget diagram showing the short-wave (a) and long-wave (b) energy fluxes. Source: Banks, David. An Introduction to Thermogeology: Ground Source Heating and Cooling. Wiley-Blackwell, 2012.
Fig.4: Historical earth sheltered homes. Source:

- B. Rudofsky. Architecture without Architects. Doubleday \& Company, 1964.

- A. Jideofor. "Earth shelters; A review of energy conservation properties in earth sheltered housing," Energy Conservation, pp.127, 2012.

- C. von Dronkelaar. Underground Buildings. Thesis / University Of Technology Eindhoven, 2013.

Fig.5: Typology of earth sheltered buildings. Source: H. Hassan. Analytical Study of Earth-Sheltered Construction and its Suitability for Housing Projects in the Egyptian Deserts. Thesis, Egypt. 2009.

Fig.6: Deduced eight types of courtyard houses which represent the case studies

Source: Reasearchers.

Fig.7: Factors that affect earth pipe cooling performance. Source: K.H. Lee and R. Strand. "Implementation of an earth tube system into energy plus program," Energy and Buildings, vol.40, 2006.

Fig.8: Schematic diagram of integrated earth to air heat exchanger and solar chimney. Source: $M$. Maerefat and A. Poshtiri, 2010.

Fig.9: a.R1 Model in Energy Plus Program, b. R1-R8 house types Source: Researchers.

Fig.10: Average monthly temp. compared to calculated soil temp. in Aswan. Source: Researchers.

Fig.11. Average monthly temperatures compared to calculated soil temp.in Ismailia. Source: Researchers.

Fig.12: Yearly discomfort hours [Measured for the four plans (O-A-B-C)] Source: Researchers.

Fig.13. Energy consumption to reach thermal comfort [Measured for the two plans, P (O- B)]. Source: Researchers.

Fig.14: \% Decrease in energy consumption (\% Difference between Plan PO\& PB) for the two directions of the eight types. Source: Researchers. 